\title{
A new Chorizococcus species (Coccoidea, Pseudococcidae) from Taiwan with transferring of Chorizococcus mirzayansi Moghaddam to genus Spilococcus Ferris
}

\author{
Ming-Yu Tsai ${ }^{1, \dagger}$, Wen-Jer Wu ${ }^{1,2, \neq}$ \\ I Department of Entomology, National Taiwan University, Taipei 106, Taiwan 2 Research Center for Plant \\ Medicine, National Taiwan University, Taipei 106, Taiwan \\ † urn:lsid:zoobank.org:author:8D61AD20-2234-4ABC-8D62-3FFA3998A391 \\ ¥urn:lsid:zoobank.org:author:0D8FD718-ABDD-4517-AD67-EB5B6A77216E \\ Corresponding author: Wen-JerWu (wuwj@ntu.edu.tw)
}

Academic editor: Mike Wilson | Received 9 March 2011 | Accepted 26 April 2011 | Published 10 June 2011

urn:lsid:zoobank.org:pub:43AEA448-0E1C-4F30-89CF-C9D7806A4A15

Citation: Tsai MY, Wu WJ (2011) A new Chorizococcus species (Coccoidea, Pseudococcidae) from Taiwan with transferring of Chorizococcus mirzayansi Moghaddam to genus Spilococcus Ferris. ZooKeys 103: 27-40. doi: 10.3897/ zookeys.103.1215

\begin{abstract}
A new mealybug species, Chorizococcus zoysiae sp. n., feeding on Zoysia tenuifolia (Poaceae), is described from Taiwan. Adult female, third-instar female, second-instar female and first-instar nymph were described and illustrated in this article. Keys are provides to (a) separate this new species from similar species of Chorizococcus and those of same genus on zoysia grasses and (b) to identify instars of the new species. In addition, Ch. mirzayansi Moghaddam is transferred to the genus Spilococcus as S. mirzayansi (Moghaddam), comb. $\mathbf{n}$.
\end{abstract}

\section{Keywords}

Chorizococcus zoysiae sp. n., Zoysia tenuifolia, Pseudococcidae, Taiwan, Spilococcus mirzayansi comb. n.

\section{Introduction}

Zoysia grasses (Zoysia spp.) are creeping grasses native to southeastern and eastern Asia and Australasia. Because of high tolerance to temperature, sunlight, and water, they are widely used for lawns in different climate regions. According to Ben-Dov et al. (2010),

Copyright M.Y.Tsai, W.J.Wu. This is an open access article distributed under the terms of the Creative Commons Attribution License, which permits unrestricted use, distribution, and reproduction in any medium, provided the original author and source are credited. 
there are nine scale insects found on zoysia grasses, and five of them belong to the family Pseudococcidae. Among these species, Chorizococcus rostellum (Lobdell) was found on an undetermined Zoysia species.

The mealybug genus Chorizococcus includes 56 described species, half of them from the Nearctic region and others from another five regions (Ben-Dov et al. 2010). Although the genus is of worldwide distribution, many of the species are restricted to a limited area, except $C h$. rostellum which is distributed in four biogeographic regions. Although six Chorizococcus species are known from the Oriental region and occurred in India and Sri Lanka, so far there is no species have been reported from Southeast Asia. This genus has been reported on 117 plant species belonging to 25 plant families. Among them Poaceae and Asteraceae are major host plant families (Tang 1992, BenDov 1994, Ben-Dov et al. 2010, Fallahzadeh et al. 2010, Moghaddam 2010). There are very specific discussions on the genera Chorizococcus, Spilococcus and Vryburgia on cerarii numbers and other characters of these genera. In the other hand, the generic status of Ch. mirzayansi Moghaddam is questionable due to the number of cerarii, and some taxonomic works should be made.

In this paper, we provide taxonomic descriptions and illustrations of the adult female, third-instar female, second-instar female and first-instar nymph of a new Chorizococcus species. In addition, a key is provided to separate this new species from Ch. kandyensis and Ch. rostellum which are occurred around the Southeast Asia and another key is proposed for distinguishing different stages of this new species. We here transfer Ch. mirzayansi Moghaddam to the genus Spilococcus as S. mirzayansi (Moghaddam) concerning to the original description of this species.

\section{Materials and methods}

All mealybug specimens were slide-mounted in Euparal using the method outlined in Williams and Granara de Willink (1992), except that xylene was used instead of clove oil.

The morphological terms used in the descriptions are explained by Williams (2004) and Williams and Granara de Willink (1992). The descriptions and measurements are based on more than 10 slide-mounted specimens, all in good condition, except for second instar female and first instar nymph of which eight and four specimens were available, respectively. All measurements are given as minimum and maximum. Holotype measurement is also provided in parentheses. Tarsal lengths excluded the claw. Setal lengths included the setal base. Each figure shows a generalized individual based on some specimens used for the description. The enlargements around the central drawing are not drawn to the same scale as each other.

All type specimens of the new species are deposited at Department of Entomology, National Taiwan University, Taipei, Taiwan (NTU), except for three female paratypes deposited in the insect collection of the Taiwan Agricultural Research Institute, Wufeng, Taichung, Taiwan (TARI), and another three female paratypes deposited at the Natural History Museum, London, UK (BMNH). 


\section{Taxonomy}

Key to Chorizococcus species on zoysia grasses and Ch. kandyensis

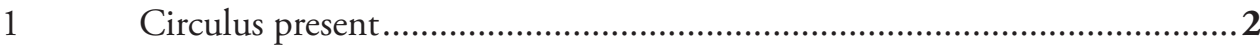

- $\quad$ Circulus absent ................................................... Chorizococcus zoysiae sp. n.

2 Ventral oral rim tubular ducts present; many dorsal oral rim tubular ducts present and extend from marginal areas to medial areas of head and thorax ..

Chorizococcus kandyensis

- Ventral oral rim tubular ducts absent; seldom dorsal oral rim tubular ducts present in marginal areas of head and thorax only ... Chorizococcus rostellum

\section{Key to instars of Chorizococcus zoysiae sp. $\mathbf{n}$.}

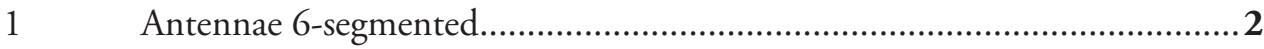

- Antennae 7- or 8-segmented ............................................................... 3

2 Oral rim tubular ducts present............................... second-instar female

- Oral rim tubular ducts absent ................................... first-instar nymph

3 Antennae 7-segmented; without multilocular disc pores; without vulva third-instar female

- $\quad$ Antennae 8-segmented; with multilocular disc pores; with vulva adult female

\section{Chorizococcus McKenzie, 1960}

http://species-id.net/wiki/Chorizococcus

Chorizococcus McKenzie 1960: 692; 1967: 86; Miller and Mckenzie 1971: 569; Williams 1970: 124; Williams 1985: 75; Williams 2004: 106; Williams and Watson 1988: 31; Williams and Granara de Willink 1992: 100; Ben-Dov 1994: 82.

Diagnosis. Body elongate oval to broadly oval; membranous. With 1-5 pairs of cerarii present on posterior segments of abdomen and sometimes a pair on head also, each cerarius bearing 2 conical setae; auxiliary setae present on anal lobe pair only. Oral rim ducts, sometimes of 2 sizes, present on dorsum and commonly also on venter. Oral collar tubular ducts present, at least on venter; if present on dorsum, then restricted to marginal areas. Antennae each with 7 or 8 segments. Legs well developed, with translucent pores on hind coxae, sometimes absent. Claw stout, without a denticle. Claw digitules knobbed. Tarsal digitules minutely knobbed. Multilocular disc pores present on venter, rarely found on dorsum. Circulus present or absent, when present usually divided by intersegmental line. Anal ring normal, bearing 6 setae. Anterior and posterior ostioles present. 
Comments. Chorizococcus McKenzie comes close to Vryburgia De Lotto in possessing dorsal oral collar tubular ducts. Oral collar tubular ducts on dorsum in Chorizococcus occur on margin only, whereas in Vryburgia, those ducts occur in transverse rows on dorsum (Williams 2004). Spilococcus Ferris is almost identical with Chorizococcus McKenzie but possesses 6-17 pairs of cerarii, six or more of which present on the abdomen. Miller and Mckenzie (1973) discussed the difficulties of assigning species to either Chorizococcus or Spilococcus. Danzig (1998) did not accept Chorizococcus and included all species with 1-17 pairs of cerarii in Spilococcus sensu lato. Here we follow the definition of Wiliiams (2004) and accept the usage of Chorizococcus McKenzie.

Spilococcus mirzayansi (Moghaddam, 2010), comb. n.

http://species-id.net/wiki/Spilococcus_mirzayansi

Chorizococcus mirzayansi Moghaddam 2010: 64.

Comments. According to the descriptions of Ch. mirzayansi, it should not be placed in genus Chorizococcus based on possessing more than 5 pairs of cerarii, a major diagnostic character in distinguishing genus Chorizococcus from genus Spilococcus in Williams's definition (2004) or it should be included in genus Spilococcus sesu lato proposed by Danzig (1998). A new combination is made here for Ch. mirzayansi as above.

\section{Chorizococcus zoysiae Tsai, sp. n.} urn:lsid:zoobank.org:act:F243D130-D94E-4650-B741-5AD0FB364531 http://species-id.net/wiki/Chorizococcus_zoysiae

Material studied. Holotype: adult female, Taiwan, Tainan City, East district, on leaf sheaths of Korean velvet grass (Zoysia tenuifolia), 7.XI.2006, S. K. Chen (NTU): 1/1 in good condition.

Paratypes: 13 adult females, 13 third-instar females, 8 second-instar females, 4 first-instar nymphs, same data as holotype (NTU); 3 adult females, same data as holotype (TARI); 3 adult females, same data as holotype (BMNH).

Description of the Adult Female. Field Features. Body color dark-brownish, covered with thin white mealy wax. Adult female and older nymphs with white, filamentous wax secretion resembling "fur" and covering both mealybug and host plant (Fig. 1). All stages of this mealybug stayed beneath the leaf sheath.

Slide-Mounted Features (measurements based on 20 specimens). Body elongate oval, 1.57-2.56 (2.44) $\mathrm{mm}$ long and 0.76-1.33 (1.17) $\mathrm{mm}$ wide (Fig. 2). Antennae each 233-267 (247) $\mu \mathrm{m}$ long, with 8 segments, occasionally 7 segments. Clypeolabral shield about 119-151 (144) $\mu \mathrm{m}$ long. Labium about 111-122 (117) $\mu \mathrm{m}$ long, shorter than clypeolabral shield. Legs well developed, stout; fore legs: coxa ca. 61-111 (94) $\mu \mathrm{m}$ long, trochanter + femur 206-233 (217) $\mu \mathrm{m}$ long, tibia + tarsus 178-206 (194) $\mu \mathrm{m}$ long, ratio 


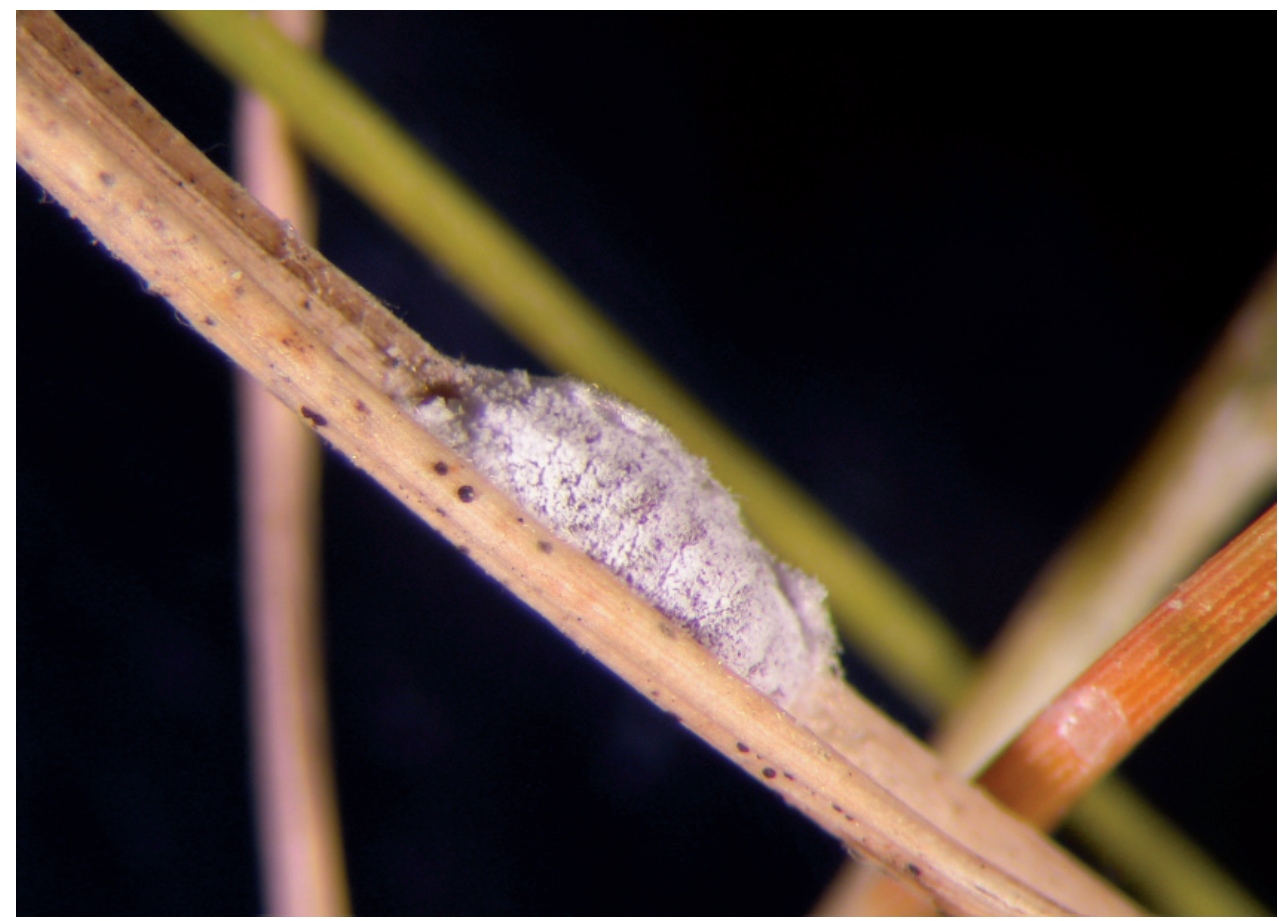

Figure I. Live adult female of Chorizococcus zoysiae Tsai, sp. n., on Zoysia tenuifolia.

of lengths of tibia + tarsus to trochanter + femur 0.81-0.95 (0.90), ratio of lengths of tibia to tarsus 1.49-2.00 (1.69); mid legs: coxa ca. 94-117 (97) $\mu \mathrm{m}$ long, trochanter + femur 222-250 (217) $\mu \mathrm{m}$ long, tibia + tarsus 189-217 (194) $\mu \mathrm{m}$ long, ratio of lengths of tibia + tarsus to trochanter + femur $0.81-0.90(0.83)$, ratio of lengths of tibia to tarsus 1.64-2.09 (1.96); hind legs: coxa ca. 97-133 (111) $\mu \mathrm{m}$ long, trochanter + femur 239-269 (256) $\mu \mathrm{m}$ long, tibia + tarsus 217-250 (244) $\mu \mathrm{m}$ long, ratio of lengths of tibia + tarsus to trochanter + femur 0.87-0.98 (0.96), ratio of lengths of tibia to tarsus 1.78-2.50 (2.14); claw stout, without denticle, about 25-26 (25) $\mu \mathrm{m}$ long. Translucent pores numbering 11-20 (13), present on posterior surface of hind coxa. Circulus absent. Both anterior and posterior ostioles present, not well developed, each lip with a few trilocular pores and $1-4$ setae. Cerarii numbering usually 2 pairs, situated on posterior abdominal segments, occasionally 3 pairs. Anal lobe cerarii $\left(\mathrm{C}_{18}\right)$ each bearing 2 slender conical setae, each seta about 18-25 (21) $\mu \mathrm{m}$ long, with 6-9 auxiliary setae and 16-20 trilocular pores. Penultimate cerarii $\left(\mathrm{C}_{17}\right)$, each containing 2 slender conical setae, about 15-22 (19) $\mu \mathrm{m}$ long, and few triocular pores. Antepenultimate cerarii $\left(\mathrm{C}_{16}\right)$, if present, each bearing 2 slender conical setae, about 14-18 (16) $\mu \mathrm{m}$ long, and few trilocular pores. Each cerarius situated on a membranous area. Anal lobes moderately developed, each ventral surface membranous, bearing an apical seta 111-144 (139) $\mu \mathrm{m}$ long. Anal ring about 46-68 (62) $\mu \mathrm{m}$ long and 57-73 (65) $\mu \mathrm{m}$ wide, bearing 6 setae, each seta about 99-138 (112) $\mu \mathrm{m}$ long.

Dorsum. Dorsal surface with slender but stiff setae present, mostly each 13-28 (18) $\mu \mathrm{m}$ long, associated by shorter setae of different sizes, about 5-7 (7) $\mu \mathrm{m}$ long, 


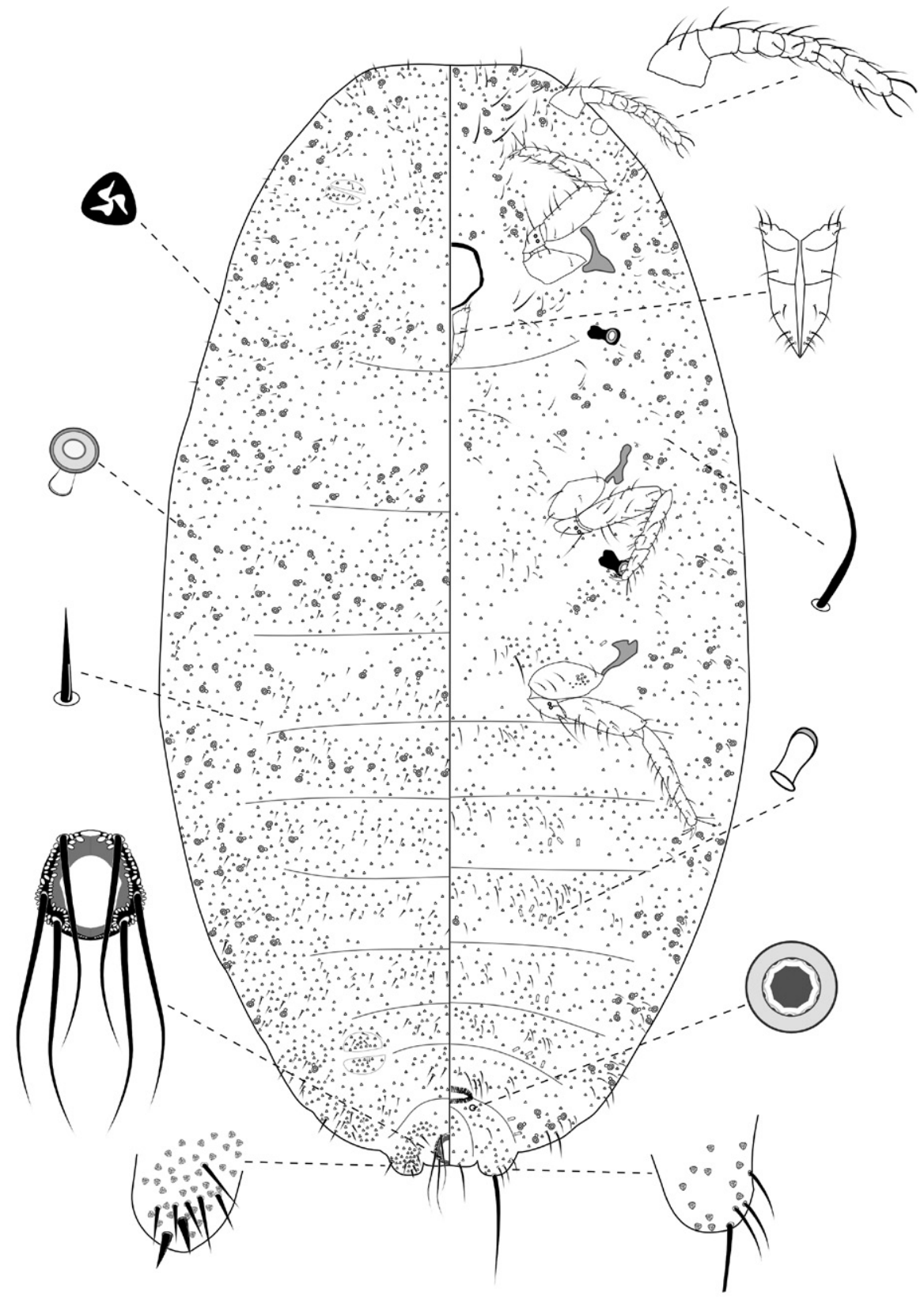

Figure 2. Adult female of Chorizococcus zoysiae Tsai, sp. n.

except for longer setae on abdominal segment VI and VII, each about 35-38 (36) $\mu \mathrm{m}$ long. Triocular pores present, each ca. $4 \mu \mathrm{m}$ in diameter, scattered over dorsum. Multilocular disc pores absent. Oral rim tubular ducts, each with rim about 6-10 (6) $\mu \mathrm{m}$ in diameter and tube about 6-8 (8) $\mu \mathrm{m}$ long, present around lateral margins forwards 
from abdominal VI to head; extending across head, thorax and abdominal I and II, forming double to triple rows in each segment. Oral collar tubular ducts absent.

Venter. Ventral surface with normal flagellate setae present, mostly each 22-51 (30) $\mu \mathrm{m}$ long, many of them longer than those on dorsum, associated by shorter setae of different sizes, about 5-11 (11) $\mu \mathrm{m}$ long, except for longer setae on head, each about 65-152 (67) $\mu \mathrm{m}$ long. Trilocular pores present, each ca. $4 \mu \mathrm{m}$ in diameter, similar to those on dorsum, scattered over venter. Multilocular disc pores small, each about 5-7 (6) $\mu \mathrm{m}$ in diameter, present around vulva only, few in number, totaling no more than 4. Oral rim tubular ducts, each with rim about 6-9 (9) $\mu \mathrm{m}$ in diameter and tube about 6-8 (6) $\mu \mathrm{m}$ long, similar to those on dorsum, each with rim wider than multilocular disc pores, distributed sparsely in marginal and submarginal zones, occasionally found in median zone. Oral rim tubular ducts absent from abdominal segment VIII. Oral collar tubular ducts about 5-7 (6) $\mu \mathrm{m}$ long and 2-3 (3) $\mu \mathrm{m}$ wide, present from abdomen III to VII, each segment with 4 to 8 , located in submedial zone.

Comments. This new species comes close to Chorizococcus kandyensis (Green, 1922) from Sri Lanka (redescribed by Williams 2004). Both species possess dorsal oral rim tubular ducts extending across head, thorax and abdominal I and II, and ventral multilocular disc pores around vulva only. However, the new species possesses 3 pairs of cerarii (Ch. kandyensis possesses only one pair) and oral rim tubular ducts of a single size on venter (Ch. kandyensis possesses oral rim tubular ducts of two sizes), and lack of circulus (present in Ch. kandyensis).

The adult female can be distinguished from all other instars by presence of a vulva opening between abdominal segments VII and VIII and by the presence of multilocular disc pores posterior to the vulva and oral collar tubular ducts on ventral abdominal segments.

It is unclear whether this new species is native or introduced from other country. According to approved facilities list for import of Bureau of Animal and Plant Health Inspection and Quarantine, Taiwan, no imports of Korean velvet grass (Zoysia tenuifolia) from other countries were recorded, therefore probably this species is native species to Taiwan. But this new mealybug species apparently occurs in a limited area in Taiwan, and only few parasitoid wasps were collected or observed around them, therefore it seems that this species was possibly introduced with its host plants, with other Zoysia species, or with other plant species.

Distribution. Taiwan (Tainan City).

Etymology. The specific epithet is based on the Latin genitive of the host-plant generic name Zoysia.

Description of the Third-Instar Female. Slide-Mounted Features (measurements based on 13 specimens). Body elongate oval, 1.06-1.50 mm long and 0.53$0.78 \mathrm{~mm}$ wide (Fig. 3). Antennae each 161-211 $\mu \mathrm{m}$ long, with 7 segments. Clypeolabral shield about 106-122 $\mu \mathrm{m}$ long. Labium about 83-106 $\mu \mathrm{m}$ long, shorter than clypeolabral shield. Legs well developed, stout; fore legs: coxa ca. 50-72 $\mu \mathrm{m}$ long, trochanter + femur 133-156 $\mu \mathrm{m}$ long, tibia + tarsus 128-150 $\mu \mathrm{m}$ long, ratio of lengths of tibia + tarsus to trochanter + femur $0.85-1.00$, ratio of lengths of tibia to tarsus 


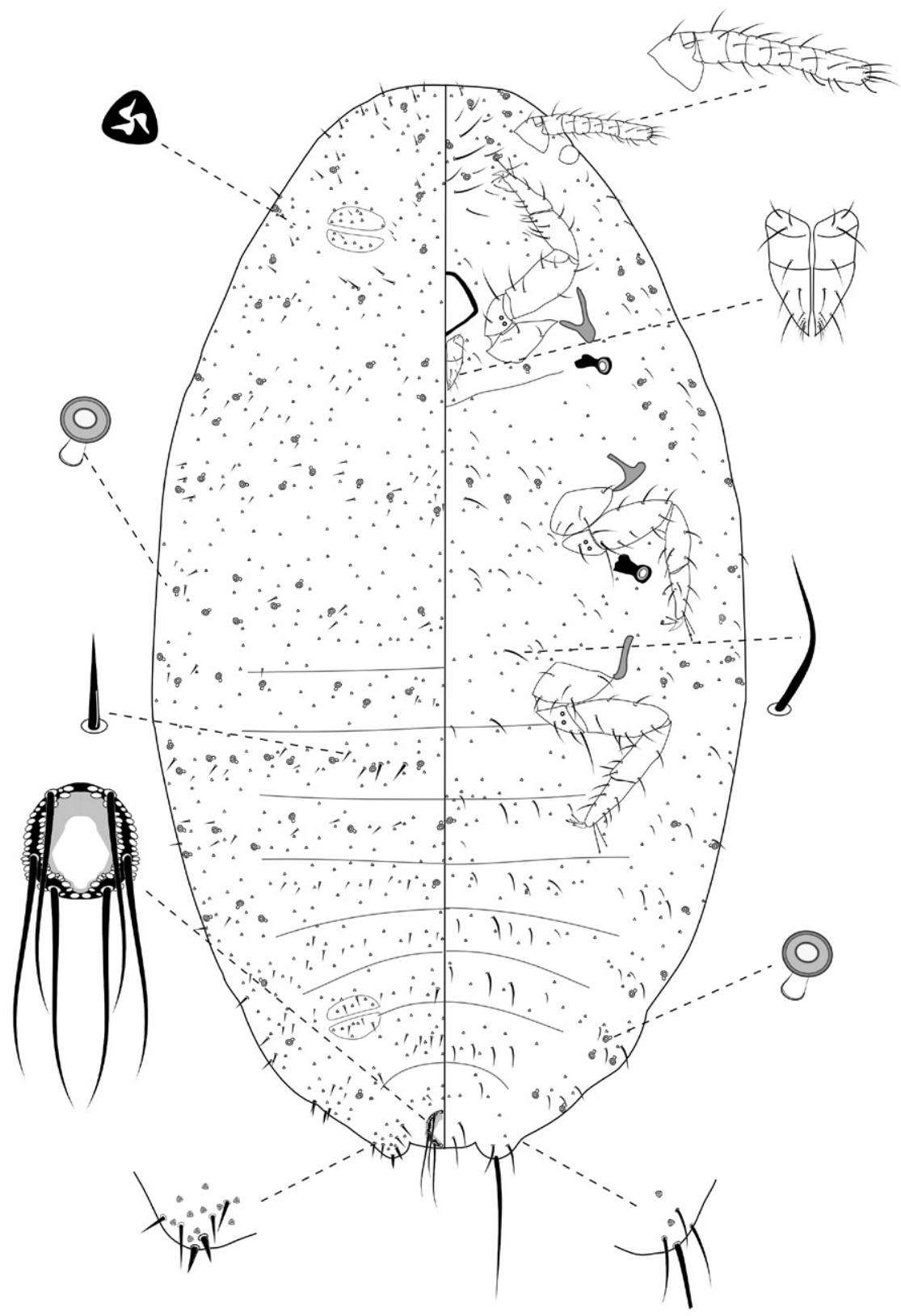

Figure 3. Third-instar female of Chorizococcus zoysiae Tsai, sp. n.

1.01-1.18; mid legs: coxa ca. 56-94 $\mu \mathrm{m}$ long, trochanter + femur 150-164 $\mu \mathrm{m}$ long, tibia + tarsus 139-176 $\mu \mathrm{m}$ long, ratio of lengths of tibia + tarsus to trochanter + femur $0.89-1.02$, ratio of lengths of tibia to tarsus 1.09-1.31; hind legs: coxa ca. 61-86 $\mu \mathrm{m}$ long, trochanter + femur 150-175 $\mu \mathrm{m}$ long, tibia + tarsus 150-172 $\mu \mathrm{m}$ long, ratio of 
lengths of tibia + tarsus to trochanter + femur $0.93-1.15$, ratio of lengths of tibia to tarsus 1.11-1.50; claw stout, without denticle, about 20-21 $\mu \mathrm{m}$ long. Translucent pores absent. Both anterior and posterior ostioles present, not well developed, each lip with a few trilocular pores and 2-3 setae. Cerarii numbering usually 2 pairs, situated on posterior abdominal segments, occasionally 3 pairs. Anal lobe cerarii $\left(\mathrm{C}_{18}\right)$ each bearing 2 slender conical setae, each seta about 16-22 $\mu \mathrm{m}$ long, with 2-6 stiff setae and $6-11$ trilocular pores. Penultimate cerarii $\left(\mathrm{C}_{17}\right)$, each containing 2 slender conical setae, each seta about 14-19 $\mu \mathrm{m}$ long, and 3-5 triocular pores. Antepenultimate cerarii $\left(\mathrm{C}_{16}\right)$, if present, each bearing 2 slender conical setae, each seta about 11-18 $\mu \mathrm{m}$ long, and $2-5$ trilocular pores. All cerarii on a membranous areas. Anal lobes moderately developed, each ventral surface membranous, bearing an apical seta $88-110 \mu \mathrm{m}$ long. Anal ring about 33-45 $\mu \mathrm{m}$ long and 46-52 $\mu \mathrm{m}$ wide, bearing 6 setae, each seta about 79-92 $\mu \mathrm{m}$ long.

Dorsum. Dorsal surface with short, stiff setae, mostly each 10-28 $\mu \mathrm{m}$ long, accompanied by shorter setae of different sizes, about 4-7 $\mu \mathrm{m}$ long. Triocular pores present, each ca. $3 \mu \mathrm{m}$ in diameter, scattered over dorsum. Multilocular disc pores absent. Oral rim tubular ducts, each with rim about 5-8 $\mu \mathrm{m}$ in diameter and tube about 5-8 $\mu \mathrm{m}$ long, present around lateral margins forwards from abdominal VII to head; extending across head, thorax and abdominal I to III, forming single row in each segment; usually only 1 on abdominal segments IV to VII.

Venter. Ventral surface with normal flagellate setae present, mostly each 13-43 $\mu \mathrm{m}$ long, many of them longer than those on dorsum, accompanied by shorter setae of different sizes, about 5-7 $\mu \mathrm{m}$ long, except for longer setae on head, each about 48-70 $\mu \mathrm{m}$ long. Trilocular pores present, each ca. $3 \mu \mathrm{m}$ in diameter, similar to those on dorsum, scattered over venter. Multilocular disc pores absent. Oral rim tubular ducts, each with rim about 5-7 $\mu \mathrm{m}$ in diameter and tube about 6-8 $\mu \mathrm{m}$ long, similar to those on dorsum, distributed in marginal and submarginal zones, occasionally found in median zone, usually in groups of 4 to 7 on head and thorax and 2 or 3 on each side of each abdominal segment. Oral rim tubular ducts absent from abdominal segment VIII.

Comments. The third-instar female can be distinguished from the adult female by lacking a vulva, multilocular disc pores, and oral collar tubular ducts; and from earlier instars by bearing seven-segmented antennae.

Description of the Second-Instar Female. Slide-Mounted Features (measurements based on eight specimens). Body elongate oval, 0.61-0.94 $\mathrm{mm}$ long and 0.38-0.44 mm wide (Fig. 4). Antennae each 133-161 $\mu \mathrm{m}$ long, with 6 segments. Clypeolabral shield about 78-94 $\mu \mathrm{m}$ long. Labium about 61-72 $\mu \mathrm{m}$ long, shorter than clypeolabral shield. Legs well developed, stout; fore legs: coxa ca. 39-44 $\mu \mathrm{m}$ long, trochanter + femur 103-111 $\mu \mathrm{m}$ long, tibia + tarsus 94-117 $\mu \mathrm{m}$ long, ratio of lengths of tibia + tarsus to trochanter + femur $0.89-1.08$, ratio of lengths of tibia to tarsus 0.89-1.25; mid legs: coxa ca. 44-50 $\mu \mathrm{m}$ long, trochanter + femur 100-117 $\mu \mathrm{m}$ long, tibia + tarsus 11 $1117 \mu \mathrm{m}$ long, ratio of lengths of tibia + tarsus to trochanter + femur $1.00-1.17$, ratio of lengths of tibia to tarsus $1.00-1.41$; hind legs: coxa ca. $44-50 \mu \mathrm{m}$ 


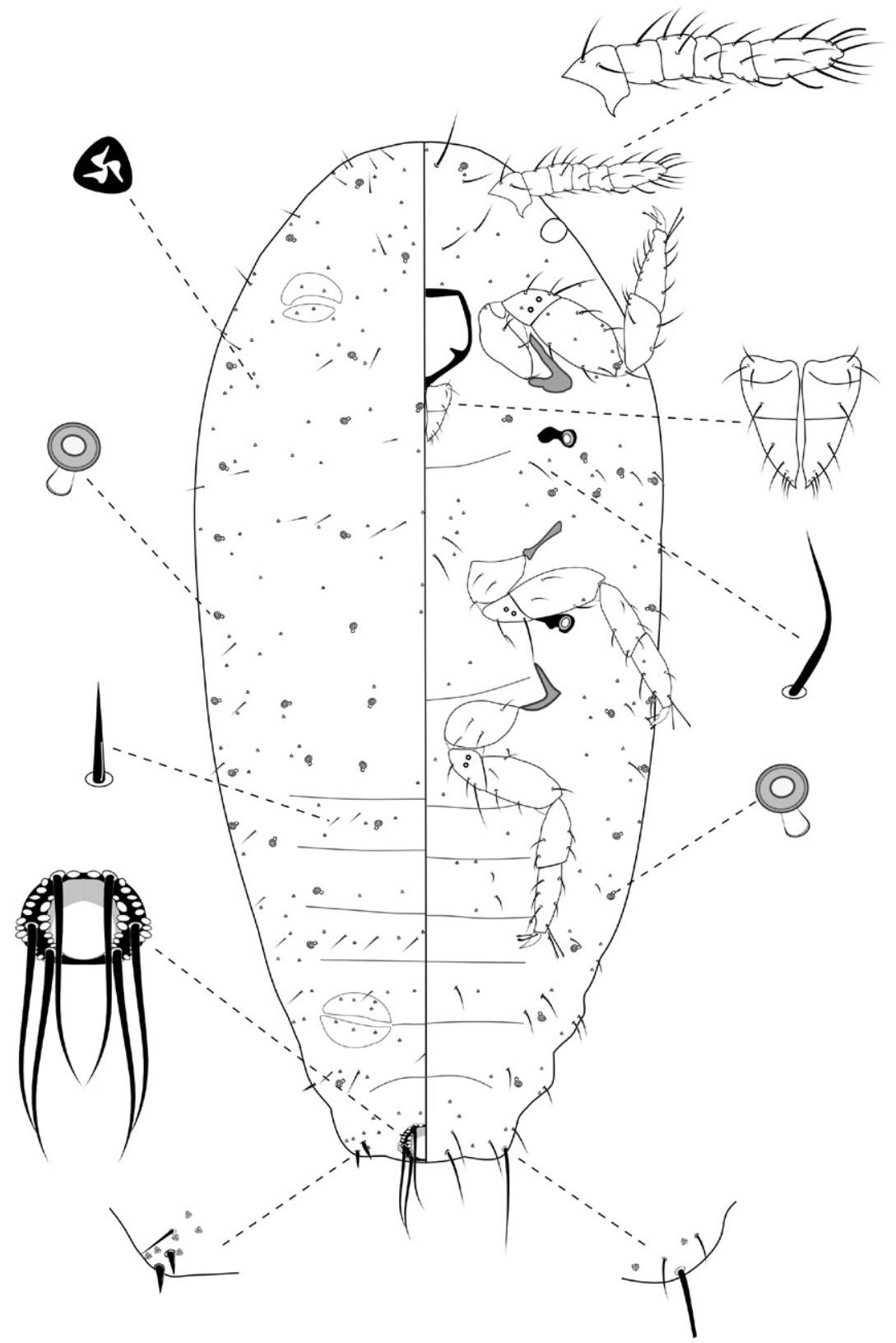

Figure 4. Second-instar female of Chorizococcus zoysiae Tsai, sp. n.

long, trochanter + femur 111-117 $\mu \mathrm{m}$ long, tibia + tarsus $117-128 \mu \mathrm{m}$ long, ratio of lengths of tibia + tarsus to trochanter + femur 1.05-1.15, ratio of lengths of tibia to tarsus 1.04-1.30; claw stout, without denticle, about 17-19 $\mu \mathrm{m}$ long. Translucent pores absent. Circulus absent. Both anterior and posterior ostioles present, not well 
developed, each lip with a few trilocular pores. Cerarii numbering usually 1 pairs on anal lobes. Anal lobe cerarii $\left(\mathrm{C}_{18}\right)$ each bearing 2 slender conical setae, each seta about 14-16 $\mu \mathrm{m}$ long, with a stiff seta and 3-5 trilocular pores. All cerarii on a membranous areas. Anal lobes slightly developed, each ventral surface membranous, bearing an apical seta 75-94 $\mu \mathrm{m}$ long. Anal ring about 22-33 $\mu \mathrm{m}$ long and 39-44 $\mu \mathrm{m}$ wide, bearing 6 setae, each seta about $61-78 \mu \mathrm{m}$ long.

Dorsum. Dorsal surface with short, stiff setae present, mostly each 5-13 $\mu \mathrm{m}$ long. Triocular pores present, each ca. $4 \mu \mathrm{m}$ in diameter, scattered over dorsum. Multilocular disc pores absent. Oral rim tubular ducts, each with rim about 5-9 $\mu \mathrm{m}$ in diameter and tube about 6-7 $\mu \mathrm{m}$ long, present around lateral margins forwards from abdominal VII to head; extending across head, thorax and abdominal I to III, forming 4 longitudinal lines on marginal and submedial areas of head and thorax; usually only 1 on abdominal segments IV to VII. Oral collar tubular ducts absent.

Venter. Ventral surface with normal flagellate setae present, mostly each 9-33 $\mu \mathrm{m}$ long, many of them longer than those on dorsum, except for longer setae on head, each about 38-52 $\mu \mathrm{m}$ long. Trilocular pores present similar to those on dorsum, scattered over venter. Multilocular disc pores absent. Oral rim tubular ducts, each with rim about $6-8 \mu \mathrm{m}$ in diameter and tube about 6-7 $\mu \mathrm{m}$ long, similar to those on dorsum, distributed in marginal zones, usually in groups of less than 6 on head and thorax and only one on each side of each abdominal segment. Oral rim tubular ducts absent from abdominal segment VIII. Oral collar tubular ducts absent.

Comments. The second-instar female can be distinguished from the third-instar female and adult female by its six-segmented antennae; and from the first-instar nymph by having oral rim tubular ducts.

Description of the First-Instar Nymph. Slide-Mounted Features (measurements based on four specimens). Body oval, $0.49-0.64 \mathrm{~mm}$ long and $0.21-0.32$ mm wide (Fig. 5). Antennae each 100-128 $\mu \mathrm{m}$ long, with 6 segments. Clypeolabral shield about 61-72 $\mu \mathrm{m}$ long. Labium about 42-56 $\mu \mathrm{m}$ long, shorter than clypeolabral shield. Legs well developed, stout; fore legs: coxa ca. 28-33 $\mu \mathrm{m}$ long, trochanter + femur 67-83 $\mu \mathrm{m}$ long, tibia + tarsus 86-94 $\mu \mathrm{m}$ long, ratio of lengths of tibia + tarsus to trochanter + femur $1.07-1.42$, ratio of lengths of tibia to tarsus $0.72-0.88$; mid legs: coxa ca. 31-33 $\mu \mathrm{m}$ long, trochanter + femur 72-83 $\mu \mathrm{m}$ long, tibia + tarsus $92-100 \mu \mathrm{m}$ long, ratio of lengths of tibia + tarsus to trochanter + femur 1.10-1.55, ratio of lengths of tibia to tarsus $0.78-0.89$; hind legs: coxa ca. 31-33 $\mu \mathrm{m}$ long, trochanter + femur 72-89 $\mu \mathrm{m}$ long, tibia + tarsus 100-111 $\mu \mathrm{m}$ long, ratio of lengths of tibia + tarsus to trochanter + femur 1.13-1.54, ratio of lengths of tibia to tarsus 0.89-1.38; claw stout, without denticle, about 11-14 $\mu \mathrm{m}$ long. Translucent pores absent. Circulus absent. Both anterior and posterior ostioles present. Cerarii numbering one pairs, situated on anal lobes. Anal lobe cerarii $\left(\mathrm{C}_{18}\right)$ each bearing 2 slender conical setae, each seta about 10-17 $\mu \mathrm{m}$ long, with 1 or 2 trilocular pores. All cerarii on a membranous areas. Anal lobes slightly developed, each ventral surface membranous, bearing an apical seta 56-75 $\mu \mathrm{m}$ long. Anal ring about 17-22 $\mu \mathrm{m}$ long and 28-33 $\mu \mathrm{m}$ wide, bearing 6 setae, each seta about 39-56 $\mu \mathrm{m}$ long. 


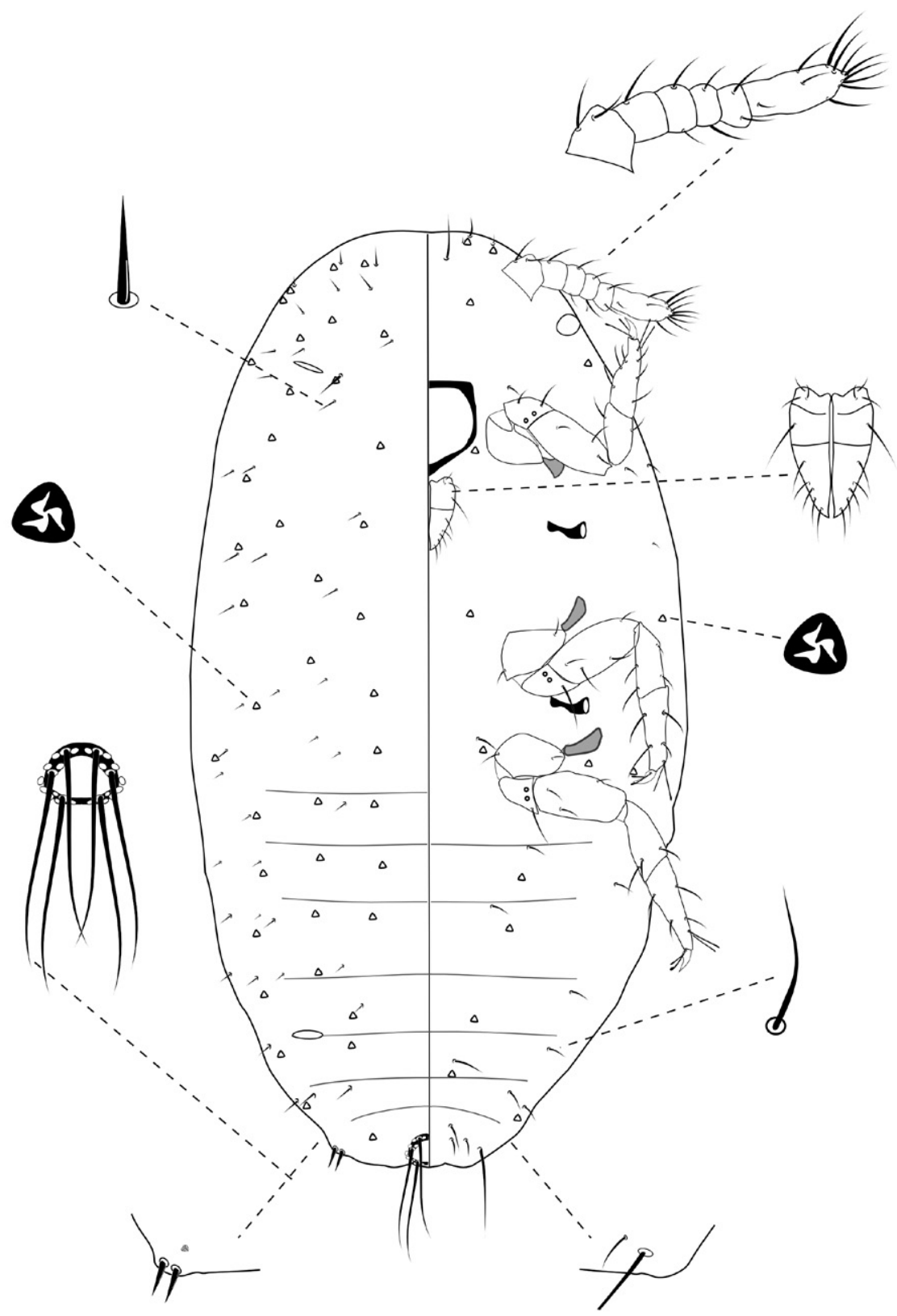

Figure 5. First instar nymph of Chorizococcus zoysiae Tsai, sp. n.

Dorsum. Dorsal surface with short, stiff setae present, mostly each 6-10 $\mu \mathrm{m}$ long. Triocular pores present, each ca. $3 \mu \mathrm{m}$ in diameter, scattered over dorsum. Multilocular disc pores absent. Oral rim tubular ducts absent. Oral collar tubular ducts absent. 
Venter. Ventral surface with normal flagellate setae present, mostly each 11-19 $\mu \mathrm{m}$ long, many of them longer than those on dorsum, except for longer setae on head, each about 23-30 $\mu \mathrm{m}$ long. Trilocular pores present, each ca. $3 \mu \mathrm{m}$ in diameter, similar to those on dorsum, scattered over venter in a few number. Multilocular disc pores absent. Oral rim tubular ducts absent. Oral collar tubular ducts absent.

Comments. The first-instar nymph can be distinguished from all instars by lacking oral rim and tubular ducts. It shares six-segmented antennae with the second instar, but its antennae are shorter than $130 \mu \mathrm{m}(133-161 \mu \mathrm{m}$ in second-instar females).

\section{Acknowledgements}

The authors express their appreciation to D. Rédei (Department of Zoology, Hungarian Natural History Museum, Hungary), H. T. Shih (Agricultural Research Institute, Taiwan), G. Waston (California Department of Food and Agriculture, Sacramento, CA), and S. A. Wu (Department of Forestry Protection, Beijing Forestry University, China) for opinions on manuscript. Thanks are extended to S. K. Chen (Tainan District Agricultural Research \& Extension Station, Council of Agriculture, Taiwan) for assistance in collecting materials.

\section{References}

Ben-Dov Y (1994) A systematic catalogue of the mealybugs of the world (Insecta: Homoptera: Coccoidea: Pseudococcidae and Putoidae) with data on geographical distribution, host plants, biology and economic importance. Intercept Limited, Andover, UK, 686 pp.

Ben-Dov Y, Miller DR, Gibson GAP (2010) ScaleNet: a database of the scale insects of the world. http://www.sel.barc.usda.gov/scalenet/scalenet.htm [accessed 9.XII.2010]

Danzig EM (1998) Revision of mealybugs (Homoptera, Pseudococcidae) with oral rim tubular ducts of the fauna of Russia and neighbouring countries. Entomological Review 78: 54-78.

Fallahzadeh M, Kaydan MB, Kozár F (2010) Description of a new species of Chorizococcus (Hemiptera: Coccoidea: Pseudococcidae) infesting Vitis vinifera in Iran. Turkiye Entomoloji Dergisi 34: 157-163.

McKenzie HL (1960) Taxonomic study of California mealybugs with descriptions of new species (Homoptera: Coccoidea: Pseudococcidae). Hilgardia 29: 681-770.

McKenzie HL (1967) Mealybugs of California with taxonomy, biology, and control of North American species (Homoptera: Coccoidea: Pseudococcidae). University of California Press, Berkeley, 525 pp.

Miller DR, McKenzie HL (1971) Sixth taxonomic study of North American mealybugs, with additional species from South America (Homoptera: Coccoidea: Pseudococcidae). Hilgardia 40: 565-602.

Miller DR, McKenzie HL (1973) Seventh taxonomic study of North American mealybugs (Homoptera: Coccoidea: Pseudococcidae). Hilgardia 41: 489-542. 
Moghaddam M (2010) Two new species and a new record of mealybugs (Hemiptera, Coccoidea, Pseudococcidae) from Iran. Zootaxa 2619: 63-68.

Tang FT (1992) The Pseudococcidae of China. Shanxi Agricultural University, Taigu, Shanxi, China, 686 pp.

Williams DJ (1970) The mealybugs (Homoptera, Coccoidea, Pseudococcidae) of sugarcane, rice and sorghum. Bulletin of Entomological Research 60: 109-188. doi:10.1017/ S0007485300034209

Williams DJ (1985) Australian mealybugs. British Museum (Natural History), London, 431 pp.

Williams DJ (2004) Mealybugs of southern Asia. The Natural History Museum, London, UK, Southdene SDN. BHD, Kuala Lumpur, Malaysia, 896 pp.

Williams DJ, Granara de Willink MC (1992) Mealybugs of Central and South America. CAB International, London, England, 635 pp.

Williams DJ, Watson GW (1988) The scale insects of the tropical south Pacific region. Part 2: The mealybugs (Pseudococcidae). CAB International Institute of Entomology, London, 260 pp. 